\title{
Homophonous Realization of Contrastive English Lexical Items: The Case of the English Spoken in Some Ghanaian Schools
}

\author{
Isaac Danquah Darko, M.Phil. \\ Ghana Technology University College, Ghana
}

URL:http://dx.doi.org/10.19044/1lc.v6no2a4

\begin{abstract}
This study explores the lexical difference between the British Standard English - the Received Pronunciation (RP) and the English spoken by students in Ghanaian Senior High Schools, and identifies homophonous realizations in the students' (Ghanaian) pronunciations. This was based on the findings of earlier research on English pronunciation in Ghana: Dako (2001), Adjaye (2005), Koranteng (2006), etc., that the English spoken in Ghana is distinctive in its features, and thus different from other English accents. It was further based on the Accent Phonology Theory by Trubetzkoy (1931) that accents may vary at various levels, and that two accents may have the same set of phonemes but differ in the selection of phonemes for words (Lexical differences). Data for the study comprised two sets of words and sentences which respondents had to read out for recording and transcription, using RP as a reference point. The result showed that out of 100 pairs of words looked at in the study, 67 were rendered homophonous in the respondents' pronunciations, although such words have contrastive pronunciations in RP.
\end{abstract}

Keywords: Homophones, pronunciation, vowel and consonant sounds, monophthongs, diphthongs.

\section{Introduction}

All languages structure meaning at the level of the word, sentence or discourse. At all the levels of meaning, the word is very crucial since the meaning of a sentence or discourse depends on the meaning of the words which are its constituents. Words have form and meaning. There are spoken forms and conventionally accepted written forms. It is necessary therefore to distinguish a word (considered as a composite unit) from both the form and its meaning, in-order to reduce the ambiguity associated with some words. One spoken form (homophones) may have different written forms and meanings (Lyons, 1995:25). Homophones has in recent years become a subject that is of 
interest to Linguistics and Communications scholars. The confusion of homophones has very serious negative implications on writing. Inappropriate use of homophones can create confusion and problems in the writing industry, business or academic papers. It also makes students get low grades. (Shoemaker, 2008).

Second language situations are no exception to the problems associated with homophones. And in Ghana, where English, although prestigious (plays an important role in politics, business, justice administration, the mass media, commerce, religion, and education), is a second language, it is not uncommon for students to write sentences such as these:

He toured the hole country. (whole)

The teacher will site an example in the class. (cite)

There was mud on the souls of her feet. (soles)

Second language varieties are however characterized by some linguistic features that might not be present in native-speaker varieties. In Ghana therefore, it is once again not uncommon for students to write such sentences as:

He will consult as. (us)

He forced her to drink the staff. (stuff)

The student was sucked for stealing. (sacked)

It must be noted that words like as/us, staff/stuff, and sack/suck are not homophones in the English language, but tend to be pronounced the same way in Ghana (making them homophones,) hence their confounding.

Although context helps in disambiguation, there are some situations that context cannot help much. An example is when at a stadium, a police officer intending to command his subordinates to shoot into the clouds, as a warning to calm irate spectators, ordered, "Shoot into the crowds." The result of this was disastrous. The context could not help to disambiguate the command the officer gave.

It is important therefore for studies to be conducted in this area of sense relations to create awareness of such words in the English Language.

Although scholars like Prator (1968) have registered their objection to the acceptance of second language varieties as valid, second language varieties of English continue to emerge, and are acknowledged by scholars such as Bamgbose (1996:9), Owusu Ansah (1997:24) and Adjaye (2005:277). Koranteng (2006) believes that the pronunciation of English in Ghana must be seen as a distinctive form that distinguishes the Ghanaian from other speakers of English; a form that can be called Ghanaian English (GhE).

Taking into consideration the propositions and assertions based on research conducted by the aforementioned linguists and researchers, it would be so unfair to base this study on British English or American English norms, 
instead of a Ghanaian English norm. Words which are pronounced the same (homophones) in Ghana may not have the same pronunciation in other English norms, and vice versa. There is the need therefore to initially find the words which are not homophones in the English language, and yet are pronounced the same way by Ghanaians. Such words, in Ghana, are of the same features as the established homophones in the English language - they are pronounced the same way, though they have different spelling and different meaning. Ghanaians don't speak English with the RP (Koranteng, 2006), the basis for most of the established homophones in the English Language. Moreover, RP has lost the recognition and prestige it used to enjoy (Quartey, 2009:3).

\section{Purpose of the study}

This study sought to identify words that are not homophones in RP and yet have the same pronunciation in GhE. GhE differs from RP at various levels. The research therefore aimed to identify and present a compilation of such homophones in the English spoken by students of some SHSs. In so doing, awareness of the situation will be created.

\section{Research questions}

Questions which helped to achieve the research objectives included these:

- What are the words that are not homophones in English, and yet are pronounced the same way

by SHS students in Ghana?

- What are the causes of such homophones?

\section{Literature and theoretical basis}

Homophones are words which have the same pronunciation, but different spelling and meaning. This is what Lyons (1995:25) refers to as one spoken form with different written forms and meanings. Yule (1996:120) asserts that when two or more different (written) forms have the same pronunciation, they are described as homophones, while the term homonymy refers to one form (written and spoken) with two or more unrelated meanings. In other words, words which have the same pronunciation and spelling but different meanings are homonyms. Thus homophony (same pronunciation) and homography (same spelling) make homonymy (same pronunciation and same spelling but different meanings). For example:

bank (side of a river) bank (turn, as in aeroplane)

capital (of a country) capital (blown out of proportion)

However, if the meanings of such words (with the same pronunciation and the same spelling) are related, they are polysemous. Such words include:

cup (a vessel for drinking) cup (the hand)

mouth (part of human body) mouth (bottle) 
There is the need therefore to differentiate homophony from homography, homonymy, and polysemy. Lyons (1995: 55) asserts that the traditional definition that, homonymy is different words with the same form, is "to say the least, imprecise." The term word is ambiguous and could be substituted for 'lexeme.' However the definition remains defective since it fails to take into account that most lexemes in most languages have several forms. The definition also says nothing about grammatical equivalence. He therefore establishes a concept absolute homonymy, as opposed to partial homonymy. Absolute homonyms must have unrelated meaning and identical forms which are grammatically equivalent, e.g. sole (bottom of foot or shoe), sole (kind of fish). Partial homonyms have identity (minimal) of one form and at least another (not all) of the conditions stated for absolute homonymy. E.g. found (past/past participle of find), found (to establish).

According to Sekyi-Baidoo (2002:172), for words to be considered pure homophones, they should exhibit the same suprasegmental features (stress pattern), apart from having the same phones. This means that such words should be pronounced the same way. He is of the view that homophones and homographs (homonyms) are the most common source of lexical ambiguity. In the case of homophones, it is only in speech that the ambiguity can be noticed; in spelling their difference is clear. The problem with homophones however is the difficulty to select the appropriate writing form for a particular context. This may result in sentences which are absurd.

Shoemaker (2008) on the other hand describes homophones as words that sound alike, while having different meanings. He draws a difference between the confusion of homophones and malpropism, which is an intentional misuse of words to create confusion and humor.

The source of homophones in the English language can be traced to the lack of correspondence between the pronunciation and spelling of English words. A study of English (British or GAE) pronunciation and spelling has shown that there is absurdity in English spelling. This absurdity is attributed to the lack of regularized correspondence between the sound of a word in standard speech and its expression in written symbols. Valins (1949) attributes this to various reasons:

In the first place the English alphabet or stock of symbols is deficient in written letters, and contains others that are not necessary. Indeed, twenty vowel sounds (pure vowels and diphthongs) are represented by just five written letters. The result is that one letter or symbol may represent more than one sound and one sound may be represented by more than one symbol, thereby creating homophones and homographs - homonyms. 
Eg. /s/ is represented by different symbols in the homophones cite / site, cell/ sell, while / $\mathrm{s}$ / / has different representation of symbols in laud / lord.

Secondly, the modern fixed spelling system, which dates only from the eighteenth century, is based on history (the original formation of words) rather than their actual sound in present day speech; it is etymological, rather than phonetic. Words that have different spelling and different meanings may therefore have the same pronunciation (homophones). Eg. Air / heir, eyes / ice.

Finally, changes in the sound of words naturally may be faster than changes in their written form. Spelling lags behind pronunciation. The pronunciation of some words can change to coincide with other pronunciations, but spelling may remain the same over a long period, resulting in homophones. (P. 110 - 129)

The final situation is true of English in the Ghanaian situation pronunciation of English words by some Ghanaians change to coincide with other pronunciations.

Though it is quite challenging to deal with homophones, scholars suggest regular reading as a means by which their confusion can be minimized, if not prevented. Reading enhances knowledge of the meanings and different spellings of words which are pronounced the same way, and the spelling that is appropriate in a particular context.

Judith Backley (2009) in an article, Easy Ways to Distinguish Difficult Homophones, suggests that homophones can be distinguished by their meanings, usage, word class and their compounds. For example, 'affect/effect,' 'bare/bear,' and 'passed/past' can be distinguished by word class (their parts of speech), while 'cite/site/sight' could be distinguished by their compounds such as 'recite/website/eyesight.' It must be noted here that re-cite $\rightarrow$ recite is more of affixation than compounding, suggesting that homophones can also be distinguished by the affixes they take.

Writing in the Daily Graphic (December 19, 2008:11), Africanus Owusu Ansah states that it is imperative to consider words which are often confused, "not because they are homophones or homonyms but because they often get mixed up." Such words include 'border/bother,' 'cease/seize,' and 'faithful/fateful.' For example, "Both speakers highlighted important issues bothering on race, education, conflict resolution ..." Although Owusu Ansah did well by drawing attention to such words, what he failed to recognize is that the confounding of such words emanates from same pronunciation (i.e. homophones) by those who confuse them.

Dolphyne (1999:97) states that most of the mistakes that are made in spelling can be traced to mispronunciation of words, in which pairs like 'tend/turn'; 'touch/torch' and 'leaving/living' are given the same 
pronunciation. Huber (2008:75) on the same phenomenon states that there is the tendency in GhE to neutralize the distinction that exists between some RP vowels, resulting in homophony of RP minimal pairs. In all of this, they don't disagree with Adjaye in their general findings, though the details or statement (wording) may have some variations.

Similar to Huber (2008), Dako (2001) and Koranteng (2006), Adjaye (2005) which provides the basis for this work gives revealing features that make GhE distinctive. She used a total of 38 respondents whose educational level ranged from first cycle to tertiary. With regard to their L1, 15 spoke Akan, 12 spoke Ewe while 11 spoke Ga (p.30-34). She concluded that there is a Ghanaian English accent. It has a '16 - term vowel system' that is characteristically Ghanaian. There can however be up to ' 20 terms' in some individuals' idiolects. The difference between RP vowels and GhE vowels is the absence of / $\Lambda, \nu, \partial, 3:$ / in GhE. RP /3:/ is merged with /3ə/ and both realized as [ $\varepsilon:], / \Lambda /$ is merged with $/ æ /$ and realized as [a], or with $/ \mathrm{p} /$, realized as [o]; $/ \mathrm{v} /$ is merged with $/ \mathrm{u}: /$ and realized as $[\mathrm{u}]$; final open $/ \mathrm{a} / \mathrm{with} / \mathfrak{x} /$ is realized as [a], non-final, broadly as $[\varepsilon, \mathrm{a}, \rho]$ according to spelling. In addition RP

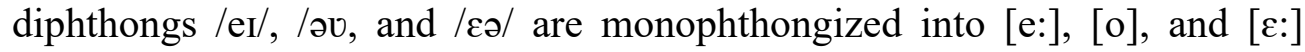
respectively.

With regard to consonants, Adjaye (2005) asserts that out of the $24 \mathrm{RP}$ consonants - / p, b, t, d, k, g, f, v, $\theta$, , , s, z, J, 3, h, t f, dz, m, n, y, 1, r, j, w/, GhE has 20. / $/ \theta /, / \delta /, / 3 /$, and $/ \mathrm{y} /$ are not phonemes in GhE. $/ 3 /$ and $/ \mathrm{y} /$ may be realized as variants of $/ \mathrm{J} /$ and $/ \mathrm{n} /$ respectively. There can however be all the 24 $\mathrm{RP}$ vowels in the idiolects of some GhE speakers.

Apart from its segments, other features that make GhE distinctive include the tendency for:

- Vowel Elision

The shwa vowel /o/ in a non-final position is elided. E.g. bursary [bezri]

- Consonant Cluster Deletion

Yod - deletion, i.e. /j/ deletion in initial clusters of words like student, human, stupid and during.

At word-medial cluster, $/ \mathrm{k}, \mathrm{g} /$ is elided before another consonant. For example: accident ['asident ' asidənt]; exept [ $\varepsilon$ ' sept]; exam ['Ezam]; exactly [E'zatli].

Reduction in two term, three term and four term final clusters, like affect [a'fet]; contact ['kontat kontat]; context ['kbntest]; next [nest]; texts $[\mathrm{t}$

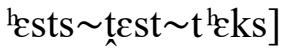

- Metathesis of /s/ and /k/ in /_sk/ clusters, as in ask [aks aks]; desk [d $\varepsilon \mathrm{ks} \sim \mathrm{d} \varepsilon \mathrm{ks}]$ 
- Vowel nasalization in the vicinity of nasal consonants. For example mean [mĩ:n]; never [nẽva]. (Dolphyne 1965:50, cited by Adjaye 2005).

- Realizing the past/past participle $\left\{\_\right.$ed $\}$as voiced (_d/_əd) irrespective of its environment.

- Realizing the noun plural/ possessive or third person singular $\left\{\_s\right\}$ as voiceless (_s/_Is) irrespective of its environment.

- Stress shift in multi-syllabic words. (Koranteng, 2006:333)

The work uses these findings to identify mergers in GhE, of RP contrastive pronunciations.

This work is also within the purview of the Accent Phonology Theory propounded by Trubetzkoy (1931) and re-echoed by Gimson (2001:84) to show the differences between accents. It states that the differences that exist between accents can be looked at on four levels:

- Systemic differences.

- Realization differences.

- Lexical differences.

- Distributional differences.

This work compares the RP accent with the accent that is used by the respondents $(\mathrm{GhE})$ to particularly identify the incidence of lexical variations resulting in the same pronunciation (homophones) of contrastive pronunciations in RP.

\section{Methodology and Data Collection Selection of Educational Level}

The Senior High School (SHS) level was selected for this work, particularly because that is the highest level at which all students receive intensive tuition with regard to the English language. This does not mean that English is not taught at levels higher than SHS; there are Departments of English and Linguistics which offer undergraduate and postgraduate programs for some university students. However, except for a year or less lessons on communication skills for all tertiary level students, and tuition in the teaching of English for teacher trainees, most educated Ghanaians cease intensive studies of the English language after SHS. The kind of English they speak is basically what they learnt from the primary level up to SHS level, in spite of their higher education. In addition to the SHS being the level at which there is serious teaching and learning of English for all students, it is also the point of convergence for students from different parts of the country. Those whose English show features of L1 transference not shared by other Ghanaians therefore have the opportunity to reshape the way they speak English. This means that using the SHS for this study will help identify the shared features 
of English as it is spoken by Ghanaians. The SHS level is therefore crucial when it comes to the kind of English Ghanaians speak.

\section{Selection of Schools}

Four public senior high schools were randomly selected for this study. The schools were selected from two regions for other reasons apart from convenience. They have students from all parts of the country, and therefore cannot be said to represent just one Ghanaian ethnic group. In addition to that, it has been established that there are features of GhE that are common to all Ghanaians irrespective of their L1 or the part of Ghana they come from (Dako, 2001) (Huber, 2008:74). One category 'A' school and one category 'C' school (GES Categorization of Schools, 2010) were selected in each of the two regions (Eastern and Greater Accra). The category 'A' class of schools has a higher intake of students/children from English-speaking urban schools and homes than those in the other categories. The two categories were selected so that the findings can neither be said to be that of the privileged schools only, nor that of the under-privileged schools only, but a representation of the SHS system in Ghana. The category ' $A$ ' schools were, Presbyterian Boys Secondary School - Legon, and Aburi Girls Secondary School, while West Africa Secondary School - Accra, and Presbyterian Secondary School Begoro, constituted the category ' $\mathrm{C}$ ' schools selected.

\section{Selection and Description of Respondent}

Five students were selected from each of the four schools making a total of twenty respondents. Eight were General Arts students, six were Business students, and six were from the Sciences. This was once again to ensure that the respondents fairly represent SHS students. To ensure gender fairness, ten of the respondents were females while the other ten were males. To qualify as a respondent one needed to have been a student of the selected school for at least one year, and must speak at least one Ghanaian language. It was to ensure that the respondents had spent some time at the SHS level and so must have had the opportunity to reshape the way they speak English. In other words, they must have the shared features of English as it is spoken by Ghanaians, having spent at least a year in the school. The table below provides information on respondents' sex, age, home town, place of residence, and the languages they speak, apart from English.

\section{Data Collection}

The data for analysis in this study consisted of sentences which respondents had to read out. Their readings were recorded with a very good quality recorder (Zoom H2) and saved on a computer for later listening and transcription. Before a respondent read the sentences, s/he was engaged in an 
interview to find his or her linguistic, educational and social background. It offered the chance for free speech, as well as providing information for respondents' description.

\section{Reading material}

The reading material was made up of two lists (A and B) of 100 sentences. Each sentence in list A contains a word which may be pronounced the same with a word in a corresponding sentence number in list B. Such words are not homophones in RP, but may be realized as such in Ghana due to the distinctiveness of GhE discussed in the literature.

\section{Procedure}

The respondents from Presbyterian Boys' Secondary School, Legon, were the first to be recorded. Five students were selected, but it was ensured that there was at least one student from the Sciences, Arts, and Business. The respondents were recorded one after the other in a quiet room. First was the interview, after which Set A sentences were read, followed by Set B sentences. The same procedure was repeated in the other schools.

Before every recording however, it was ensured that permission had been given by a respondent's school's authority, and the respondent had been given prior information of the recording, and that s/he was willing and ready to be recorded.

\section{Data Analysis and Discussion}

The recordings were transferred from the recorder to a computer and were transcribed using RP as a reference point. For each pair of words, the respondents' pronunciations were analyzed. If more than $50 \%$ of the respondents pronounced the pair the same way, then they could be said to have realized as homophones. However, if there was more than one same pronunciation of any pair of words, any pronunciation that qualified as a realization of the homophones was required be the realization of at least $25 \%$ of respondents. That was meant to forestall any situation where a respondent's idiolect would be taken as a general way of pronunciation of a pair.

All the symbols used by various phoneticians to represent the twenty English vowel phonemes (adapted from Awonusi, 1999:10 by Koranteng 2006:57) were considered. Gimson's (1980) was adopted for this study; however, a change was made in the transcription of vowel number 3. Vowel number 3 has been transcribed in this study as $/ \varepsilon /$, after Ida Ward (1958), Wells \& Colson (1971), and Fromkin \& Rodman (1974), instead of Gimson's /e/. That permitted differentiation between respondents' realization of vowel number $3-/ \varepsilon /$ and [e], the initial vowel sound in the diphthong /eI/. There is the tendency among Ghanaians to realize the diphthong /ei/ as [e:] 


\section{Homophonous Realization of RP Contrastive Pronunciations}

67 out of the 100 pairs of words looked at in this study are homophonous. $50 \%$ or more of respondents have the same pronunciation for the words that make each pair:

\begin{tabular}{|c|c|c|c|}
\hline $\begin{array}{l}\dot{\bar{\Xi}} \\
\text { है } \\
\bar{\Xi}\end{array}$ & \multicolumn{2}{|c|}{ Words and RP pronunciations } & \multirow{2}{*}{$\begin{array}{l}\text { Homophonous realization } \\
\text { in } \\
\qquad \text { GhE } \\
\text { /'ascnt/ }\end{array}$} \\
\hline 1 & accent /'rksant/ & assent/a'ssnt/ & \\
\hline 2 & adder /'ædə/ & 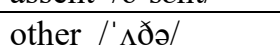 & /'ada/ \\
\hline 3 & back /bæk/ & buck /b $/ \mathrm{k} /$ & /bak/ \\
\hline 4 & bad /bæd/ & bud $/ \mathrm{b} \Lambda \mathrm{d} /$ & /bad/ \\
\hline 5 & bag /bæg/ & bug /bıg/ & /bag/ \\
\hline 6 & bat /bæt/ & but $/ \mathrm{b} \Lambda \mathrm{t} /$ & /bat/ \\
\hline 7 & bed /bed/ & bird /b3:d/ & $/ \mathrm{bcd} /$ \\
\hline 8 & brace /breis/ & braise /breız/ & /brez/ \\
\hline 9 & branch /brænt $\int /$ & brunch /brıntf/ & /brant $\int /$ \\
\hline 10 & brash /bræ $\int /$ & brush $/$ br $\Lambda \int /$ & /braf/ \\
\hline 11 & cancel /'kænsəl/ & counsel /'kaunsəl/ & /'kansəl/ \\
\hline 12 & cap /kæp/ & cup $/ \mathrm{k} \Lambda \mathrm{p} /$ & /kap/ \\
\hline 13 & cease /si:s/ & seize /si:z/ & $/ \mathrm{si} \cdot \mathrm{z}>\mathrm{si}: \mathrm{z} /$ \\
\hline 14 & cheek /t $\int \mathrm{i}: \mathrm{k} /$ & chick $/ \mathrm{t} \int \mathrm{Ik} /$ & $/ \mathrm{t} \int \mathrm{Ik} /$ \\
\hline 15 & consort /kən'so:t/ & consult /kən's $\Lambda$ lt/ & /kon'sot/ \\
\hline 16 & crash /kræ $/ /$ & crush $/ \mathrm{kr} \Lambda \mathrm{J} /$ & $/ \mathrm{kra} /$ \\
\hline 17 & crate $/$ kreit/ & create /kri'ert/ & /kret/ \\
\hline 18 & damp /dæmp/ & dump /d $\Lambda \mathrm{mp} /$ & /damp/ \\
\hline 19 & dare /d $\varepsilon \partial /$ & there /ठعə/ & $/ \mathrm{d} \varepsilon \cdot /$ \\
\hline 20 & deal /di:l/ & dill / $\mathrm{dil} /$ & $/ \mathrm{dil} /$ \\
\hline 21 & den /den/ & then /ðعn/ & $/ \mathrm{d} \varepsilon \mathrm{n} /$ \\
\hline 22 & dough /dəv/ & though /ðə৩/ & $/ \mathrm{do} \cdot /$ \\
\hline 23 & drag /dræg/ & drug /dr $\mathrm{g} /$ & /drag/ \\
\hline 24 & edge $/ \varepsilon \mathrm{d}_{3} /$ & urge $/ 3: \mathrm{d} 3 /$ & $\mid \varepsilon \mathrm{d}_{3} /$ \\
\hline 25 & fault /fo:lt/ & fort /fo:t/ & $/$ fo $\cdot \mathrm{t} /$ \\
\hline 26 & flash /flæ $/ /$ & flush $/ \mathrm{fl} \wedge \mathrm{J} /$ & /fla $/$ \\
\hline 27 & grant /grænt/ & grunt /grınt/ & /grant/ \\
\hline 28 & hag /hæg/ & hug $/ \mathrm{h} \wedge \mathrm{g} /$ & /hag/ \\
\hline 29 & hat /hæt/ & hut $/ \mathrm{h} \Lambda \mathrm{t} /$ & /hat/ \\
\hline 30 & hatch /hæt J/ & hutch $/ \mathrm{h} \wedge \mathrm{t} f /$ & /hatf/ \\
\hline 31 & heal /hi:l/ & hill /hil/ & /hil/ \\
\hline 32 & high /hai/ & hire /'haro/ & /hai/ \\
\hline 33 & just /dz^st/ & jest /dzest/ & $/ \mathrm{d} z \varepsilon s t /$ \\
\hline 34 & keel /ki:l/ & kill $/ \mathrm{kIl} /$ & $/ \mathrm{kIl} /$ \\
\hline 35 & lack /læk/ & luck /lık/ & /lak/ \\
\hline 36 & ladder /'lædə/ & lather /'læðə/ & /'lada/ \\
\hline 37 & lamp /læmp/ & lump /lımp/ & /lamp/ \\
\hline 38 & last /læst/ & lust / $/ \Lambda s t /$ & /last/ \\
\hline 39 & launch /lo:ntf/ & lunch /lınt $/$ & /lantg/ \\
\hline
\end{tabular}




\begin{tabular}{|c|c|c|c|}
\hline 40 & leave /li:v/ & live /liv/ & $/ \mathrm{li} \cdot \mathrm{v} /$ \\
\hline 41 & look /lvk/ & luke /lu:k/ & /luk/ \\
\hline 42 & $\mathrm{mad} / \mathrm{mæd} /$ & mud $/ \mathrm{m} \Lambda \mathrm{d} /$ & $/ \mathrm{mad} /$ \\
\hline 43 & mast /mæst/ & must $/ \mathrm{m} \Lambda \mathrm{st} /$ & /mast/ \\
\hline 44 & match /mæt $\int /$ & much $/ \mathrm{m} \Lambda \mathrm{t} f /$ & /mat $\int /$ \\
\hline 45 & nest /nest/ & next /nckst/ & /nest/ \\
\hline 46 & peel /pi:1/ & pill /pil/ & $/ \mathrm{pIl} /$ \\
\hline 47 & pool /pu:1/ & pull /pol/ & $/ \mathrm{pul} /$ \\
\hline 48 & potable /'pəotəbəl/ & portable /'po:təbəl/ & /'potabol/ \\
\hline 49 & price /prais/ & prize /praiz/ & /prais/ \\
\hline 50 & quiet /'kwaist/ & quite /kwart/ & $/$ kwaist $\sim$ kwait $/$ \\
\hline 51 & rash /ræ $\int /$ & rush $/ \mathrm{r} \Lambda \mathrm{J} /$ & $/ \mathrm{raj} /$ \\
\hline 52 & sack /sæk/ & suck /s $/ \mathrm{k} /$ & /sak/ \\
\hline 53 & scheme /ski:m/ & skim /skim/ & /skim/ \\
\hline 54 & slam /slæm/ & slum /slım/ & /slam/ \\
\hline 55 & span /spæn/ & spun $/ \mathrm{sp} \Lambda \mathrm{n} /$ & /span/ \\
\hline 56 & stab /stæb/ & stub/ st $\Lambda \mathrm{b} /$ & /stab/ \\
\hline 57 & staff /stæf/ & stuff /st $\Lambda \mathrm{f} /$ & /staf/ \\
\hline 58 & stamp /stæmp/ & stump /st $\Lambda \mathrm{mp} /$ & /stamp/ \\
\hline 59 & steal /sti:1/ & still /stıl/ & $/$ stil/ \\
\hline 60 & tamper /'tæmpə/ & temper /'tcmpə/ & /'tempa/ \\
\hline 61 & taught /to:t/ & thought $/ \theta$ o:t/ & $/ \mathrm{tot} /$ \\
\hline 62 & tend /tend/ & turn /t3:n/ & $/ \mathrm{t} \varepsilon \mathrm{n} /$ \\
\hline 63 & test /test/ & text /tckst/ & $/ \mathrm{t} \varepsilon \mathrm{st} /$ \\
\hline 64 & tie /tai/ & tyre /'taiə/ & $/ \mathrm{tai} /$ \\
\hline 65 & tongs /tonz/ & tongues $/ \mathrm{t} \wedge \mathrm{yz} /$ & $/$ tons $>$ tans/ \\
\hline 66 & track /træk/ & truck $/ \operatorname{tr} \Lambda \mathrm{k} /$ & /trak/ \\
\hline 67 & wean /wi:n/ & win /wIn/ & /win/ \\
\hline
\end{tabular}

\section{Tendencies that Result in Homophony of RP Contrastive Pronunciations}

The homophony of the words was as a result of certain 'tendencies' (Huber, 2008) that Ghanaian speakers of English exhibit. They are the same tendencies that mark out the Ghanaian from other speakers of English, (Dako 2001). The conversion of the pairs into homophones was due to one or a combination of these tendencies:

- Merger of two or more RP sounds and given one realization (coallescence). Words that are contrastive only in such sounds become homophonous. The data reveal that $/ \mathfrak{x} /, / \mathrm{N} /$, and $/ \mathrm{\jmath} /$ were realized as $/ \mathrm{a} /$. Words like staff/stuff, damp/dump, slam/slum, etc. which are contrastive only in $/ \mathfrak{x} /$ and $/ \Lambda /$, therefore become homophonous.

- Replacement of segments of some words with others. The resulting pronunciation in such cases may coincide with others, making them homophonous. In the homophony of wean/win, 
steal/still, and peal/pill, the long front high vowel /i:/ is replaced with the short one $/ \mathrm{I} /$.

- Deletion

segments.

Deletion of a segment of a word may also result in homophony. That is when the elided segment or syllable is what differentiates the word's pronunciation from that of other words. For instance deletion of $/ \mathrm{k} /$ from the cluster /_kst/ results in the homophony of test/text, and nest/next. In accent/assent, / $\mathrm{k} /$ is deleted from the cluster/_ks_/.

- Reduction in the number of syllables of some words. The homophony of some RP contrastive lexical items is as a result of reduction in the number of syllables of some words. Crate/create are homophonous because create, a di-syllabic word, is realized as monosyllabic.

- Insertion of sounds or segments in words. Homophony of RP contrastive words may also be due to insertion of a segment or segments in some words. The pronunciation of such words may change to coincide with those of others. For example the shwa vowel in quiet/'kwarat/ is replaced with /E/. The removal of this segment from quiet or it's insertion in quite renders them homophonous - quiet/quit /'kwaret 'kwart/.

- Monophthongization of RP diphthongs and diphthongization of RP triphthongs. Two words may be the same in all segments, except that one has a diphthong and the other has a monophthong. Such words are different in their realizations. However if the diphthong is monophthongized, the pronunciation of both words become the same, and therefore renders them homophonous. A word that contains a triphthong too may change to coincide with the pronunciation of other words, if the triphthong is reduced to a monophthong. Cancel/counsel become homophonous because the diphthong in counsel/au_/ is made a monophthong /a/ which is also the realization of /æ/ in cancel. The two words therefore become homophonous. Similarly, high/hire, and tie/tyre become homophonous because the triphthong in hire, as well as tyre /aiə/ is diphthongized.

- Voiced realization of segments which are voiceless in RP. Words may be different in pronunciation only because a segment in one differs just in voicing from a similar segment in a similar position of the other. Such words become homophonous when the voicing of the contrastive segments are made the same. Cease/seize, and brace/braise are homophonous because the voiceless alveolar fricative sound /s/ in cease and brace are made voiced /z/ to coincide with the pronunciation of seize and brace respectively. 


\section{Other Tendencies}

Respondents exhibited other additional tendencies. These are tendencies which may not directly result in homophony of RP contrastive words, but are worthy of note since they confirm the findings of earlier research in GhE pronunciation. Such tendencies may also lead to contrastive pronunciation of RP homophones such as miner/minor/'maina/ $\rightarrow$ miner/'maina/and minor/' maIno/, one/won /wsn/ $\rightarrow$ one /wan/, and won /won/.

- Absence of Weak forms.

RP weak forms are made strong but are said on a low tone to differentiate them from stressed syllables. Thus a low tone replaces an unstressed syllable, and the shwa vowel which marks most unstressed syllables in RP is therefore seldom used. For instance, ladder/'lædə/ is realized as /'lada/, temper/'tzmpə/ as /'tempa/, and lather/'læðə/ as /'lada/.

- Reduction in the length of long vowels. This does not result in homophony, but may make homophones differ in pronunciation. It must be noted that short vowels differ from long vowels not only in length but in quality too. Just reducing the length of a long vowel will therefore not make it coincide with a short vowel. Both the length and quality need to change to coincide with a short vowel, before homophony may result. It cannot therefore be just reduction in length of a long vowel but rather a Replacement. /u:/, /o:/, and /i:/ are reduced in length in pool/pul/, taught/tot/, and wean/win/ respectively.

- Absence of secondary stress. With word stress the data revealed that stress placement in two/three syllable words is not different from that of RP. However secondary stress in words such as ideal is not realised - ideal/, aı' dıəl/ is realized as /aı' dıl >aı' dil/.

- Substitution of the glottal stop for plosive sounds. This is a tendency among young Ghanaians, and could be attributed to the inroads that American English is making into Ghanaian English. This usually happens to the voiceless alveolar stop in the final position of words like but [ba?]. (Page 47).

\section{Factors Leading to the Tendencies}

- L1 transference.

The influence of the L1 of Ghanaian speakers of English may also result in coalescence of RP segments, which may also result in homophony of RP contrastive pronunciations. Two or more sounds may be merged and given a preferred realization based on speakers'

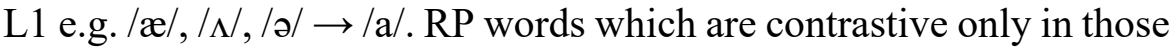


segments become homophones. The combinatorial factors of speakers' L1 too may be taken over to English. Vowel harmony requires that only vowels of one set occur in polysyllabic words. This may make certain words select other sounds than what is in RP. The result then will be replacement or coalescence, which may further result in homophony. Accent and assent are pronounced the same way partly due to the transfer of vowel harmony to English. (Page 41)

- Simplification of English

Little or slight differences in the pronunciation of certain words are taken for granted. The production and pronunciation therefore, of similar but not same sounds and words, are made the same; usually by the realization of the most popular or frequently occurring.

- Spelling pronunciation

- Analogy.

Some words are pronounced based on analogy. That is pronouncing a word based on experience with similar words, and the result may not be the same as it is in RP. It may result in insertion, replacement, deletion, etc. and may result in homophony. For instance, words like pool /pu:1/, tool /tu:1/, food /fu:d/, inform the pronunciation of look $/ \mathrm{lu}: \mathrm{k} /$, which is homophonous with luke /lu:k/; however /u:/ is reduced in length, making both look and luke realized as /luk/.

- GhE operates on a reduced number of sounds, compared with RP.

Thus the forgoing tendencies as exhibited by the respondents (second language speakers of English) resulted directly or indirectly in the homophonous realization of contrastive English words. These are tendencies that characterize second language varieties, making them distinctive from other varieties.

\section{Conclusion}

This study sought to identify and compile RP contrastive pronunciations that are homophonous in the English spoken by the respondents. It was also to create awareness of the situation and confirm the findings of earlier research on GhE pronunciation, which also provide the basis for this study.

The Accent Phonology Theory by Trubetzkoy (1931), re-echoed by Gimson (2001) was used to identify particularly, the lexical variations that exist between RP and the English spoken by the respondents and which result in the homophony of RP contrastive pronunciations. It was also to find the causes of the homophonous realizations. 
67 out of one hundred pairs of contrastive words were found to be homophonous in the English spoken by the respondents. (Refer - Data Analysis and Discussion)

It was also found that some RP homophones like miner/minor, one/won are pronounced differently. All these differences in RP and the English spoken by the respondents come about due to one or a combination of certain tendencies, which are further due to certain factors that affect the way they speak English.

The findings go to confirm earlier research findings that the English spoken by Ghanaians is distinctive. Words which are homophonous therefore in GhE may not be homophonous in RP and other accents of English, and vice - versa. The way such words are treated (whether pronounced the same or not) may affect spelling and usage, which may in turn affect meaning and communication in general.

Although, the decision to give recognition to such homophonous realizations of contrastive RP words is beyond the scope of this work, if the findings of earlier research on GhE is anything to go by, then such homophonous realizations of contrastive RP words may provide useful information for students, teachers, journalists and all those who use English for communication either in Ghana or with Ghanaians. If Ghana would however still regard its English as British Standard, and therefore continue to use RP to examine students who neither speak with that accent nor are taught by teachers who can speak with it, then a lot more needs to be done to provide the right models for teachers and students in order to improve on the prevailing situation.

\section{References:}

1. Adjaye, S. A. (2005). Ghanaian English Pronunciation. New York: The Edwin Mellen Press.

2. Ahulu, S. (1944). How Ghanaian is Ghanaian English? English Today 38: $25-29$.

3. Awonusi, V. O. (1999). Coping with English Pronunciation. Obaroh \& Ogbinaka Publishers Ltd.

4. Backley, J. (2009). Easy Ways to Distinguish Difficult Homophones. Retrieved from http//research-writingtecniques.suit101.com/article.cfm//.

5. Bamgbose, A. (1996). Non-Native Englishes on Trial. In M. E. Kropp Dakubu, (Ed) pg. 9 - 22, English in Ghana. Accra: Black Mask Publishers.

6. Dalton, C. \& Seidlhofer, B. (1994). Pronunciation. Oxford: Oxford University Press. 
7. Dako, K. (2001). The Sound System of Ghanaian English. In Exploration: Journal of the English Department. Vol. 1, No.1: pg. 107119.

8. Dolphyne, F. A. (1999). The Teaching of Spoken English. In M. E. Kropp Dakubu, (Ed), Teaching English in Ghana. Accra :Ghana English Studies Association.

9. Ellis, R. (1994). The Study of Second Language Acquisition. Oxford University Press.

10. Gimson, A. C. (2001). Gimson's Pronunciation of English (6th ed) revised by A.Cruttenden. Arnold Publishers.

11. Grieve, D. W. (1964). English Language Examining. African University Press.

12. Huber, M. (2008). Ghanaian English: Phonology. In Varieties of English: Africa, South and Southeast Asia, pg. 67 - 91. Berlin:Mouton de Gruyter.

13. Jenkins, J. (2000). The Phonology of English as an International Language: New Models, New Norms, New Goals. Oxford University Press.

14. Jones, D. (1960). An Outline of English Phonetics (9th ed), London: CambridgeUniversity Press.

15. Koranteng, L. A. (2006). Ghanaian English: A Description of its Sound System and Phonological Features. Unpublished Ph.D. Thesis, University of Ghana.

16. Longman (1995). Dictionary of Contemporary English. Edinburgh: Pearson EducationLimited.

17. Lyons, J. (1977). Semantic 2. Cambridge: University Press.

18. Lyons, J. (1995). Linguistic Semantics: An Introduction. Cambidge: University Press.

19. McArthur, T. (1992). The Oxford Companion to the English Language. Oxford

20. University Press.

21. Owusu-Ansah, A. (2008). Homophones and Homonyms. Daily Graphic, Dec.19, pg.11.

22. Owusu-Ansah, L. (1997). Nativisation and the Maintenance of Standards in Non-Native

23. Varieties of English. In M. E. Dakubu (ed.) pg.23-33 English in Ghana. Accra:

24. Black Mask Publishers.

25. Prator, C. H. (1968). The British Heresy in TESL. In J. A. Fishman, C. A. Ferguson and

26. J. Das Gupta(eds.), Language Problems of Developing Nations. New York: John 
27. Wiley \& Sons pp. 459-76.

28. Quartey, E. (2009). Phonological Features of English as Spoken by Some Final Year

29. Senior High School Students in Ghana. Unpublished M.Phil. Thesis, University

30. of Ghana.

31. Roach, P (1991). English Phonetics and Phonology. Cambridge: Cambridge University

32. Press.

33. Sackey, J. (1997). The English Language in Ghana: A Historical Perspective. In M.E.

34. Dakubu (ed.) pg.126-139 English in Ghana. Accra: Black Mask Publishers.

35. Sekyi-Baidoo, Y. (2002). Semantics: An Introduction. Kumasi-Ghana: Wilas Press Ltd.

36. Sey, K. A. (1973). Ghanaian English: An Exploratory Survey. London: Macmillan.

37. Shoemaker, R. (2008). Grammar Help: Homophones.2008. Retrieved from

38. http://languagestyle.suit101.com/article.cfm//.

39. Trubetzkoy, N. S. (1949), Principles de Phonologie. transl. J. Cantineau, Paris: Klinksiek.

40. Trudgil, P. (1944). The Dialects of England. Cambridge: Blackwell Publishers.

41. Valins, G. H. (1949). The Making and Meaning of Words. London: Adam and Charles

42. Black.

43. Winford, D. (2003). An Introduction to Contact Linguistics. Malden: Blackwell.

44. Yule, G. (1996). The Study of Language. Cambridge: Cambridge University Press. 


\section{APPENDICES}

WORD LIST A

Accent, adapt, adder, aerial, author, back, bad, bag, bat, beach, beat, bed, boot, brace, branch, brash, breather, cancel, cap, cease, cheek, chide, consort, corporate, crash, crate, damp, dare, deaf, deal, defile, den, dine, dose, dough, drag, each, eat, edge, fault, flash, formal, grant, hag, hat, hatch, heal, heat, high, ideal, intend, just, keel, lack, ladder, lamp, last, laud, launch, leak, leap, leave, look, mad, mast, match, miss, nest, packet, peak, peel, pool, potable, price, quarry, quiet, rash, read, reap, sack, scheme, seat, seek, seep, slam, sleep, span, stab, staff, stamp, steal, tamper, taught, tend, test, thin, tie, tongs, track, wean, Miner, one.

\section{WORD LIST B}

Assent, adopt, other, area, utter, buck, bud, bug, but, bitch, bit, bird, booth, braise, brunch, brush, breeder, counsel, cup, seize, chick, child, consult, culprit, crush, create, dump, there, death, dill, defy, then, thine, those, though, drug, itch, it, urge, fort, flush, former, grunt, hug, hut, hutch, hill, hit, hire, idle, in-turn, jest, kill, luck, lather, lump, lust, loud, lunch, lick, lip, live, luke, mud, must, much, mix, next, pocket, pick, pill, pull, portable, prize, query, quite, rush, rid, rip, suck, skim, sit, sick, sip, slum, slip, spun, stub, stuff, stump, still, temper, thought, turn, text, tin, tyre, tongues, truck, win, Minor, won. 